\title{
Luso-Brazilian Co-Productions: Rescue and Expansion
}

Natália Pinazza

The emphasis of this chapter will be on the role played by audio-visual policies and co-production initiatives in Brazilian and Portuguese national cinemas in a globalized context. The aim of this chapter is to argue for the continued relevance of national frameworks for the analysis of transnational filmmaking practices and to emphasize how supranational community discourses can inform both the production and subject matter of film. The chapter will also consider how the labelling of Luso-Brazilian coproductions affects concepts that feature prominently in contemporary academic discourse, such as 'European cinema' and 'Latin American cinema', and, with broader theoretical implications, the binary approach of 'national' versus 'transnational'.

Although there is an increasing number of texts dealing with the transnational features of Iberian and Latin American cinema, only a handful of these analyse in depth the theoretical implications of the particularities of agreements involved in international film co-productions. These include, for instance, Stephanie Dennison's edited volume on Contemporary Hispanic Cinema: Interrogating the Transnational in Spanish and Latin American Film (2013). Moreover, scant attention has been paid to the transnational links in the Lusophone world; the most extensive study on this topic is Carolin Overhoff Ferreira's Identity and Difference: Postcoloniality and Transnationality in Lusophone Films (2012).

There have also been a number of seminars and very recent texts dealing with issues of transantionalism (Álvarez, 2016) and postcoloniality (Sabine, 2010; Ferreira, 2014; Faulkner, 2015) in Portuguese cinema. However, there is a surprising absence 
of discussion about the fact that a former colony, Brazil, is contributing to the representations of the colonial past and postcolonialism in contemporary Portuguese national cinema through the financing of Luso-Brazilian co-productions like $A$ Primeira Missa ou Tristes Tropeços, Enganos e Urucum (Ana Carolina, 2014), O Grande Kilapy (Zézé Gamboa, 2014), Yvone Kane (Margarida Cardoso, 2014), Tabu (Miguel Gomes, 2012), Entre os Dedos (Tiago Guedes and Frederico Guerra, 2009) and Diário de um Novo Mundo (Paulo Nascimento, 2005). By shedding light onto Luso-Brazilian co-productions, this chapter will also contribute to pertinent debates regarding national and transnational cinemas in the Lusophone world.

On the one hand, the overwhelming critical concentration of literature on Brazilian cinema on international film successes such as Central do Brasil/Central Station (Walter Salles, 1998), Cidade de Deus/City of God (Fernando Meirelles, 2002) and Madame Satã (2002) has contributed to debates regarding production outside national boundaries (they all are Brazilian-French film co-productions) and shed light on the impact of globalization on contemporary Brazilian cinema (they also gained international critical appraisal). On the other, the dominance of a few international co-productions in Brazilian cinema scholarship tends to overlook state funding in bilateral and multilateral agreements, thereby downplaying the national interests informing film co-productions. Since Andrew Higson's (2006) seminal piece on the 'Limiting Imagination of National Cinema' there has been a tendency to pose national and transnational as a binary (Higbee and Lim 2010), which assumes that dependence of filmmakers on the state automatically excludes transnational film practices. For instance, drawing on the work of Shaw (2013), Vallarmea Álvarez argues that Portuguese cinema's dependence on public subsides reinforces 'the permanence of Portuguese cinema within the national paradigm' and that this model 
'impedes Portuguese films from entering the first category analysed by Shaw: transnational modes of production, distribution and exhibition' (2016: 103). Arguably this perspective on state intervention stems from understandings of Portuguese film production within the context of the New State (1933-1974). This is particularly so considering the longevity of the regime, as well as the fact that the Portuguese Cinema Institute (then IPC) created in 1971 would finance projects under the condition that they were made by a Portuguese crew and filmed in the country in order to represent the 'Portuguese spirit' and Portuguese 'collective soul'. 'However, this understanding downplays ICA's recent internationalization efforts, including film co-productions, which is one of the elements that Shaw includes in the aforementioned category (2013: 52). In arguing for the remaining importance of a national framework for the analysis of contemporary Argentine cinema, Joanna Page counters a tendency in film criticism to focus on a selected number of successful international co-productions, neglecting the role of the state and rest of the country's cinematic production. As she puts it:

Pronouncements made by critics of Latin American film concerning transnational production as the only, or principal, 'viable route' reflect something of the hegemony of neoliberal discourses, which have succeeded in presenting themselves as the only possible path for economic development (Page 2009: 14).

Such a naturalization of neoliberal discourses not only obscures issues regarding the imbalance of power that might occur in international film co-productions, but also neglects the public role of cinema. National film policies are in place to protect 
national interests and safeguard artistic production. Hence the national continues to be an important framework for the analysis of transnational films involving both Brazil and Portugal in its production, as the state run agencies in the two countries, ANCINE and ICA, respectively, remain responsible for regulating international co-production agreements.

Manoel Rangel, president-director of ANCINE, describes the bilateral film coproduction agreement with Portugal as the 'oldest and the most lasting partnership' that Brazilian cinema has (ANCINE 2013). The Luso-Brazilian Film Co-production Agreement was first signed in 1981 with a view to encourage cinematographic activity between the two countries. As part of the same agreement, the Audiovisual Development Secretary of the Brazilian Ministry of Culture and ICA (the Portuguese Institute of Cinematographic Arts and Audiovisual) created the Luso-Brazilian Film Co-production Protocol in 1994, based on the former Luso-Brazilian Co-production Agreement first signed in 1981. After changes in technological demands, the Protocol was updated in 1996 and then eleven years later in 2007. According to the Protocol, both the Brazilian and the Portuguese governments agree to finance four feature films (fiction, animation or documentary) per year. Two of each are predominantly Brazilian and two predominantly Portuguese. The predominance of one nationality in a co-production depends on the nationality of the director and the financial contribution of the country. A committee selects the projects to be funded by the Coproduction Protocol. According to ANCINE, US\$ 600,000 are invested in the four selected projects (US\$ 300,000 in two predominantly Brazilian films and US\$ 300,000 in two predominantly Portuguese films), thus benefiting film production in both countries. On the one hand the Brazilian Film Agency considers the expansion of its film production an opportunity for cultural assertion in the context of the country's 
economic emergency. On the other, Portuguese filmmakers see the bilateral agreement with Brazil as an important aid to the Portuguese film industry, currently faced with a severe crisis.

Here Ezra and Rowden's argument that transnational cinema 'transcends the national as autonomous cultural particularity while respecting it as a powerful symbolic force' (2006: 2) sheds light on how these transnational cinematic practices can work in favour of national cinema. For instance, the winner of the best national feature film at the 42nd Gramado Film Festival in 2014 in Brazil was the film $A$ Estrada 47 (Vicente Ferraz, 2013), which benefited from the Luso-Brazilian Coproduction Protocol. Likewise, along with Tabu, other films that benefited from the Protocol such as O Mistério da Estrada de Sintra (Jorge Paixão da Costa, 2007), Dot.com (Luís Galvão Teles, 2007) and José e Pilar (Miguel Gonçalves Mendes, 2010) feature in ICA's list of the top 40 most watched Portuguese national films. As is the case with other films made in a transnational context, those examples prompt a series of questions regarding how a film is framed discursively in terms of nationality and the extent to which a transnational exchange informed the final product with regards to style and aesthetics, choice of actors and subject matter. Within the understanding that transnational film practices are also shaped by national interests, this chapter will explore how Luso-Brazilian film co-productions provide insight into the relationship between the countries involved, particularly in terms of identity negotiation and their shared colonial history, as well as into the current state of Brazilian and Portuguese national cinemas.

Globalization and the national cinemas of Brazil and Portugal 
Originally established to safeguard their respective national film industries, current Brazilian and Portuguese film policies remain central to fostering national production and intergovernmental co-production agreements. Despite the adoption of a more international approach to the business of film, there is an undeniably national interest behind international film co-productions. This is especially the case for an emerging economy like Brazil, since enabling national films to compete in both the domestic and international markets is an important strategy of cultural assertion. In 2013 the president director of ANCINE put forward a political agenda for the expansion of the Brazilian audio-visual industry: 'I believe that the national development project for which we all work requires an ability to produce and export our own image [...] the good current situation in the Brazilian audio-visual industry is a social victory. It is a result of the work of public power in many instances and it provides Brazilians with a number of opportunities for employment, cultural affirmation and the flourishing of its audio-visual products' (ANCINE 2013a).

The financial incentives currently in place for the Brazilian film industry can be traced back to 1969, when EMBRAFILME (the Brazilian Cinema Enterprise) was created. Although this state film agency had been crucial for national film production since its creation, Fernando Collor de Mello, the first democratically elected president (who was later impeached for corruption), did away with EMBRAFILME in March 1990, plunging film production into deep crisis. Commenting on the severity of the crisis, José Álvaro Moisés, National Secretary for Audiovisual Affairs between 1999 and 2002, stated that, as a consequence of Collor de Mello's actions, 'national production, which had exceeded 100 films a year in the mid-1970s, was almost reduced to zero, with only two films released in 1992' (2003: 7). Critics coincide in arguing that the Audiovisual Law of July 1993 was the defining element for the boom 
in Brazilian filmmaking in the mid-1990s (Moisés 2003; Oricchio 2003). This period of re-emergence, also known as retomada, was marked by films such as Carlota Joaquina - Princesa do Brasil (Carla Camurati, 1995), O Quatrilho (Fábio Barreto, 1995) and the internationally acclaimed Central Station (Walter Salles, 1998).

As part of the consolidation of the Brazilian film industry, the Brazilian Cinema Agency ANCINE was created in 2001 to deal with concerns relating to new industrial developments, by operating aid mechanisms for production, distribution and exhibition. Since the Audiovisual Law was passed there has been a re-establishment of the Brazilian film industry, which at the time of writing shows no sign of abating. Brazil produced 129 films in 2013, surpassing the production of previous years: 83 films were made in 2012 and 100 films in 2011. The mark of 129 national films in 2013 is a far cry from the 14 films made in 1995 (ANCINE 2014c).

While the Brazilian Government has been active to take measures to produce and promote national films, internationally acclaimed Portuguese filmmakers have been vocal about their discontent with the lack of governmental attention to national cinema. As a result, the 'big names' of Portuguese cinema have signed a petition entitled 'Portuguese Cinema: Ultimatum to the Government', claiming that 'Portuguese cinema is going through a dramatic situation at this moment, with [funding] cut[s] of $100 \%$ [...] The production of new films is paralysed - and a good part of the production companies are on the verge of closing, which will cause unemployment of thousands of people - and distribution, festivals, cineclubs, and international promotion are without any support'. ${ }^{2}$

The crisis that has struck Portuguese national production has been the subject of debate in the national and international press. 'Portuguese cinema is in danger' claimed film producer Luís Urbano, together with filmmaker Miguel Gomes, in a text 
which was first divulged to the international press at the Venice Film Festival in 2013 (Gomes and Urbano 2013). Urbano and Gomes consider the negligence towards the national film industry to be a political problem and accuse the Portuguese Government of leniency with cable TV operators that contribute to a recently approved Cinema Law but do not pay the government the debts they owe. For Urbano and Gomes the opposition parties are watching the diminishment of the Portuguese Cinemathéque and the National Archive of Moving Images in silence. The 'alarm is ringing' not because of the absence of incentive laws, but because of the inaction of the debtors, and the Portuguese Government's lack of interest in and commitment towards the audiovisual sector.

The first proposal for a 'law of protection of Portuguese cinema' was drafted in 1970. The following year a law was passed creating the IPC (Portuguese Cinema Institute), which eventually came into force in 1973 . The first film production plan was approved a little before the Carnation Revolution on the 25 April 1974 and in 1994 the IPC was replaced by IPACA (Portuguese Institute of Cinematographic and Audiovisual Art). In the period of 1998-2000 a new institute was created but it was not until the adoption of new cultural policies in 2007 that the current state-run agency for cinema, ICA, was established. The law currently in force, the 'Law of Cinema Arts and Cinematographic and Audiovisual Activities', was created in 2012 and revised in 2014.

The current crisis in Portuguese cinema is not symptomatic of a lack of national policies in support of the audiovisual sector. Nor can it be said to be due to a lack of talent. Despite the crisis in the national film industry, the relevance of the work of currently active Portuguese filmmakers such as Pedro Costa, João Pedro Rodrigues and Miguel Gomes is testified by their presence at some of the most 
important film festivals across the globe, including Venice, Berlin and Cannes. The visibility of these filmmakers in such festivals is also testimony to the crucial role played by the exhibition sector in the internationalization of Portuguese cinema. Furthermore, state intervention in the cinema sector has put a support system in place to secure exhibition outlets for national production beyond national boundaries, while simultaneously guaranteeing distribution and exhibition of films from different nationalities within Brazil and Portugal. With a clear agenda to promote Brazilian audiovisual products abroad, in 2014 the 'Programme of Support for the Participation of Brazilian Films in International Festivals and Workshops' supported the exhibition of national films in renowned international film festivals including the New York Film Festival, the BFI London Film Festival, the Biarritz Festival of Latin American Cinema and the Busan International Film Festival. Similarly, ICA created its own national initiatives such as 'Programme Support for Internationalization', a competition taking place in 2016 for producers with a view to securing distribution and participation of their work in the international market. Moreover, public institutions such as Insituto Camões and Embassy of Brazil promote national cinema abroad.

International film festivals and talks have also become a platform to discuss and raise consciousness about the very state of these cinemas. In addition to Urbano and Gomes (whose statement at the Venice Film Festival was cited above), other Portuguese filmmakers and artists have used international film festivals as platforms to denounce the current state of Portuguese cinema. In an interview with the Brazilian newspaper $O$ Globo in 2012, when the award winner Sangue do meu sangue (2011) was shown for the first time in Brazil, director João Canijo stated that 'Portuguese cinema tries not to die. In Portugal there is auteur film, with some quality and global 
visibility, and there is a cinema referred to as 'commercial cinema' that does not survive in the domestic market' (cited in Fonseca 2012). The issue raised by Canijo must be situated within the wider context of Portuguese cinema's domestic market. The most watched national film between 2004 and 2014, O Crime do Padre Amaro (Carlos Coelho da Silva, 2005), had 380,671 spectators, which is especially low when compared to the $1,206,161$ spectators of the most watched film of the decade, Avatar (James Cameron, 2009). In fact, no Portuguese film features in ICA's top 40 most watched films in the country; the list itself is evidence of Hollywood's domination of the Portuguese audio-visual market (ICA 2014b).

The same domination can be observed in Brazil. 129 out of the 397 films screened in Brazilian cinemas in 2013 were national films. However, Brazil has protectionist measures in place to secure the screening of national in the domestic market, which includes paid TV channels. The most famous of these is the screen quota first introduced in the 1930 s so as to promote the competitiveness of the Brazilian products with international ones in the distribution and exhibition sectors, by establishing a law that requires that national films are screened in cinema theatres across the country. Despite their controversial nature - as state intervention potentially clashes with market interests - measures such as these appear to be effective in protecting Brazilian cinema within national boundaries. According to ANCINE, the number of Brazilian films broadcast on paid TV has increased three times in two years (ANCINE 2013b). Moreover, in 2014 a law was created so as to make the presence of national films in the national education curriculum compulsory. According to the law, national production has to be exhibited 2 hours per month in schools. 
In both the Brazilian and Portuguese cinematic contexts, understanding the national context and the agenda behind film policy is key to exploring the dynamics of the transnational exchange in bilateral or multilateral film co-production agreements. The political agenda underlying international film co-production poses important questions for the understanding of the dynamics of filmmaking, given the influence that supra-national communities have on transnational film practices. A shared history of cross-border interactions, as is the case with Portugal and Brazil, impacts the way in which projects resulting from co-production agreements can be shaped, both in terms of production and film texts.

\section{The role of co-productions in Brazilian and Portuguese cinema}

In the context of Brazil's agenda for the internationalization of film production and Portugal's endeavour to save its national cinema, co-productions have played an important role in Brazilian and Portuguese film policies. Between 2005 and 2013, 82 film co-productions involving Brazil were made as a result of a number of bilateral and multilateral agreements, amongst which $30 \%$ (24 films out of 82 ) of the international film co-productions involving Brazil between 2005 and 2013 have been made with Portugal. In addition to Portugal, Brazil has bilateral agreements with Argentina, Canada, Chile, France, Germany, India, Italy, Spain and Venezuela. It is also part of the Iberian-American Convention of Cinematographic Integration and the Latin American Film Co-production Agreement, which regulates a series of multilateral agreements with countries such as Argentina, Cuba, Mexico, Panama, Venezuela, Colombia, Ecuador, Nicaragua, Peru and Dominican Republic. Moreover, there are protocols between ANCINE and other state run agencies such as the LusoBrazilian Protocol with ICA (Portugal), INCAA (Argentina), KOFIC (Republic of 
Korea), ICAU (Uruguay) and MIBAC (Italy). Other countries that are not listed in established co-production agreements such as the aforementioned ones are also able to co-produce films with Brazil. Nonetheless, they have to meet other requirements. According to ANCINE guidelines, producer companies from countries without a coproduction agreement have to hold $40 \%$ of the copyrights of the film and at least $2 / 3$ of the artists and technicians employed must be Brazilians or have resided in Brazil for more than three years. Opportunities for international co-production involving Brazil are also prompted by events such as Film Cup, a market conference first held in 2012, which promotes encounters between filmmakers and producers from Brazil and film professionals of a chosen nation: in 2012 it was Germany, in 2013 France and in 2014 Italy.

Similarly, Portugal has co-produced films with a number of different countries. Other than Luso-Brazil Protocols, there are also Luso-Spanish Film Co-production Protocols and the Luso-French Fund. Portugal's film industry has also received financial support from other bodies, such as Ibermedia, the European Film Promotion Office, the MEDIA and Creative Europe programmes and the Council of Europe's Eurimages.

Because Brazilian and Portuguese national film policies have catered for a number of international film partnerships, rigid nationalistic approaches to these cinemas are problematic even when film production is still largely dependent on the state. Higson's statement that 'there is not a single universally accepted discourse of national cinema' (1989: 36) is relevant to consider how different film policies and agreements can shape what is considered 'national'. In the case of the Luso-Brazilian Protocol nation's participation in the co-production, namely patrimonial participation, this can be major or minor. For instance, in co-productions that are majorly Brazilian 
in terms of copyrights, there is a greater financial participation of Brazil. However, when it comes to labelling film co-productions in international film festivals, the bilateral agreement between Brazil and Portugal makes it compulsory to add the 'Luso-Brazilian Co-production' label in the credits. While labelling a film is a powerful marketing tool, having a film with two nationalities has implications for film analysis in terms of understanding the film and in relation to its national sociohistorical and cinematic context. Drawing on Anderson's concept of 'imagined communities' (1983), Higson defines national cinema in the following terms:

On the one hand, a national cinema seems to look inward, reflecting on the nation itself, on its past, present, and future, its cultural heritage, its indigenous traditions, its sense of common identity and continuity. On the other hand, a national cinema seems to look out across its borders, asserting its difference from other national cinemas, proclaiming its sense of otherness (2006: 18).

Film co-productions blur these borders between nation and others. Furthermore, the dual-nationality complicates other 'supra-national' labels as they seem to compete against themselves. For instance, Portuguese films can be discursively framed as part of European cinema (cf. Kourelou et al 2014), whereas Brazilian cinema can appear as part of Latin American cinema both in scholarship (cf. Shaw, 2003) and film festivals across the globe. Therefore, is a Luso-Brazilian co-production that is listed as both a Brazilian and Portuguese film European or Latin American? To answer this question simply by arguing that that would be a matter of whether the film is listed as majorly or minorly 'Brazilian' or 'Portuguese' is to overlook the agenda set and the impact achieved by the protocols and bilateral agreements that I have been discussing. 
The affiliations between two or more national cinemas destabilize not only the nation as a framework but other forms of rigid frameworks applied to cinema, including supra-national ones such as 'European' or 'Latin American'. This problematization of labels also poses questions about how the concepts of 'European' and 'Latin American' cinemas feature in academic discourses. In his exploration of 'European cinema', Tim Bergfelder suggests that the concept should 'include marginality and liminality' taking into account Europe's history of exile. He then states that in comparison to Hollywood, 'migration has not become an equally integral element in the discourse construction of national cinemas in Europe itself' (2005: 320). This inclusive approach is adopted in the chapter 'Europe as a Destination and Point of Departure' (Pinazza 2014) to analyse how co-productions between European countries and non-European countries such as the Luso-Brazilian ones are blurring the line between Europe and its 'others' by exploring the shared cultural legacy between the two countries, which involves migration flows from Portugal to Brazil and vice versa, as well as the exchange of filmmakers from both countries and cinematic traditions. These co-productions can thus be seen as part of what Kathleen Newman calls a 'geographical decentering of the discipline':

Areas once considered peripheral (that is, less developed countries, the socalled Third World) are now seen as integral to the historical development of cinema. The assumption that the export of European and US cinema to the rest of the world, from the silent period onward, inspired only derivative image cultures has been replaced by a dynamic model of cinematic exchange, where filmmakers around the world are known to have been in dialogue with one another's work, and other cultural political exchanges to form the dynamic 
context of these dialogues. (2010: 4)

Such dialogue can be encouraged through production, distribution and circulation initiatives and programmes within a specific region, and some of them are based on the idea of a shared culture or geographical proximity. The very existence of these co-productions foregrounds the discourses on supra-national communitybuilding that lie behind such transnational film practices. The increase in multilateral agreements is symptomatic of the erosion of the nation-state in the context of neoliberalism and has prompted the formation of new imaginaries that are not simply national in scope. The existence of a multilateral forum such as CPLP (Community of Portuguese Speaking Countries) testifies to how the Lusophone world can be considered a supra-national community with its own socio-political agenda and discourses due to its shared colonial history and linguistic bonds.

To analyse the discourses and narratives of supra-national communities that lie behind contemporary filmmaking, scholars have adopted Anderson's concept of 'imagined communities' (1983), with a view to exploring how the re-emergence of these regional (Galperin 1999), linguistic (Ferreira 2012) and diasporic (Iordanova and Cheung 2010) communities have impacted cultural studies. The Co-production Protocol between ANCINE and INCAU (Uruguayan Institute of Cinema) was originally signed in 1983 as part of a Latin American Co-production Agreement and then updated in 2006 within the framework of international cooperation established by MERCOSUR (the Common Market of the South, an economic bloc created in 1991). There have been other significant acts of cross-border cooperation amongst Brazil and MERCOSUR member countries, primarily Argentina, and an institutional body, RECAM was created in 2003 with a view to integrate audiovisual industries in 
the region. Likewise, Portuguese cinema has benefited from initiatives that aim to strengthen national cinemas through regional integration, such as the aforementioned MEDIA Programme - the EU's initiative renamed Creative Europe in 2014. This type of cinematic transnationalism has been defined by Mette Hjort as 'affinitive transnationalism', 'a concept of ethnic, linguistic, and cultural affinity that was believed to make cross-border collaboration particularly smooth and therefore costefficient, pleasurable, and effective' (2010: 17). But such communities also rely on the notion of a shared historical legacy or cultural proximity, as is the case with the IBERMEDIA programme and the bilateral agreement and film co-production protocol between Portugal and Brazil. Luso-Brazilian film co-productions exemplify such decentering, both as cooperations between a South American and a European country and as forms of interaction between a former colony and its colonizer. In fact, these new forms of cooperation have also impinged on the content and aesthetic of the films often due to co-production requirements such as nationality of cast and crew. In LusoBrazilian co-productions, the common language spoken in the two countries makes it easier for actors and crew to interact, reducing costs of translation of official documents. As a result of the economic imperatives of funding, there is a marked presence of Brazilian actors in films considered 'predominantly Portuguese' and viceversa. Portuguese director Margarida Cardoso explains that in order to secure Brazilian funding, she wrote a letter to the well-known Brazilian actress Irene Ravache, who accepted a role in Yvone Kane (2014) (Faulkner and Liz 2016). Cardoso considered that Ravache's attempt to reproduce a European Portuguese accent made the character's accent unidentifiable, which contributed to the filmmaker's aim to de-territorialise the subject matter. At times, the required presence of a Brazilian or Portuguese actor is more easily justified when there is a bi-national 
narrative, which 'works as a natural bridge between the two countries and thus results as a credible co-production plot' (Falicov 2013: 71), such as Terra Estrangeira/Foreign Land (Walter Salles and Daniela Thomas, 1995), set both in Brazil and Portugal. The presence of Portuguese actors is also justified by the figure of the conquistador, a trope found in bi-national narratives portraying the colonising mission. For instance, Portuguese actor Rui Unas as Pero Vaz de Caminha in Primeira Missa ou Tristes Tropeços, Enganos e Urucum and Rogério Samora as a Portuguese lieutenant in Diários de um Novo Mundo.

Another requirement, which forms the first of the Luso-Brazilian Coproduction Protocol's criterium, is the 'relevance of the project regarding the point of view of the cultural relationship between the countries involved' (ANCINE 2014b). The trend of using literary texts that has marked Luso-Brazilian coproductions since the beginning of their partnership remains strong: recent literary adaptions include Os Maias (Alguns) Episódios da Vida Romântica (João Botelho, 2014), O Último Voo do Flamingo (João Ribeiro, 2011), Capitães de Areia (Cecília Amado, 2011), the aforementioned O Mistério da Estrada de Sintra and Diário de um Mundo Novo, while other films deal with the life of an author as in José and Pilar or make allusions to Lusophone literature as in O Manuscrito Perdido (José Barahona, 2010). The use of actors from both countries, the mixture of accents, and shared historical events problematize the presumed national features related to the characters and prompt the creation a common Lusophone discourse. However, in her study of Luso-Brazilian literary adaptions, Carolin Overhoff Ferreira explores how a body of films has perpetuated cultural myths of national identity, by engaging with a 'Lusophone monologue' instead of promoting a transnational dialogue. According to her, there are 'soliloquies on national pre-eminence still dominating the imaginary of 
the Portuguese speaking world' and 'the popularity of biased views reveals how deeply rooted they still are in the imaginary of a significant number of filmmakers from both sides of the Atlantic' (2012: 204). Indeed, although some Luso-Brazilian co-productions have often turned to their linguistic bonds and shared literary heritage to create films that appeal to both audiences, some of those films address concerns that do not appear to be equally pertinent to both countries. In this regard, when explaining the financing of the co-production Yvone Kane, Margarida Cardoso asserts that Brazil 'is not normally so sensitive to African colonial subjects' and yet was an important funder. This is a two-fold movement that reveals how Luso-Brazilian film co-productions can engage with a transnational Lusophone dialogue while reasserting interests that are rooted in national concerns.

\section{Conclusion}

The success of the Luso-Brazilian co-production Tabu in 2012 shows the significance of international co-productions, even from a standpoint of the national cinema culture, in a globalized market. The film brought a lot of attention to Portuguese filmmakers and prompted debates in international film festivals about the current situation of film production in Portugal - a debate revived by Gomes' subsequent production, As Mil e Uma Noites/Arabian Nights, in 2015. International co-production agreements have also been beneficial for Brazil's continuing objective to re-assert itself as an emerging nation through the dissemination of its culture and global promotion of its image. The recognition of cultural similarities between Brazil and Portugal that have marked these countries' filmmaking practices and that often inform their products - through the thematization of the colonial past or literary adaptions of a shared tradition problematizes discourses on regional supra-national communities that draw 
boundaries such as 'Europe' and its 'others' and 'Latin America' and its 'others'. In regard to those boundaries, Ferreira (2006) asserts that Portugal's entrance in the EU and the adoption of migration policies established by the Schengen Agreement distanced the country from its former colonies, an argument that she illustrates in her analysis of 'Luso-Brazilian brotherhood' in Foreign Land. Therefore, co-productions between Brazil and Portugal testify to the constant flux of these physical and discursive frontiers, and the role of culture within the shifting bounds of national and supra-national community building.

My focus on the co-production agreements between Brazil and Portugal is intended to counter the generalizing tendency to reduce international film cooperation into 'transnational practices' and instead enable further exploration of the uniqueness and differences amongst such practices. My approach thus aims to avoid any naturalization of 'transnationalism', which would reflect neoliberal discourses that promote internationalization as the only possible route. While this chapter testifies to the increasing importance of transnational practices, it is a contribution to adopting approaches that acknowledge that transnationalism entails different forms of practices shaped by national interests and that depends on the relationship between the countries involved in such transnational exchanges.

\section{Bibliography [check]}

Faulkner, Sally and Mariana Liz (2016), 'Portuguese Film: Colony, Postcolony memory - Q\&A with Margarida Cardoso'. Online http://www.sas.ac.uk/videosand-podcasts/culture-language-and-literature/portuguese-film-colonypostcolony-memory (accessed 15 May 2016). 
ANCINE, 2014a, 'ANCINE lança novo edital de coprodução Brasil-Portugal'.

Online. Available http://www.ancine.gov.br/sala-imprensa/noticias/ancine-lannovo-edital-de-coprodu-o-brasil-portugal (20 November 2014).

ANCINE, 2014b, 'Protocolo Luso-Brasileiro de Co-produção Cinematográfica'.

Online. Available http://www.ancine.gov.br/sites/default/files/editais-defomento/Protocolo_Luso-

BrasileirodeCoproduçãoCinematografica_11_02_14.pdf (20 November 2014).

ANCINE, 2014c, 'Dados de Mercado'. Online. Available

http://oca.ancine.gov.br/dados-mercado.htm ( 20 November 2014).

ANCINE, 2013a, 'Carta de apresentação de Manoel Rangel'. Online. Available http://ancine.gov.br/sites/default/files/apresentacoes/APRESENTACAO\%20M ANOEL\%20RANGEL\%20SENADO\%20FEDERAL\%2024042013.pdf (20 November 2014).

ANCINE, 2013b, 'Lei de cotas nacionais na TV paga vai bem'. Online. Available http://www.ancine.gov.br/sites/default/files/clipping/2013-08-08Lei\%20de\%20cotas\%20nacionais\%20na\%20TV\%20paga\%20vai\%20bem.pdf (26 May 2015).

Anderson, Benedict (2006) [1983], Imagined Communities: Reflections of the Origin and Spread of Nationalism. London: Verso.

Belinchón, Gregorio (2015), 'Las mil y una noches de la crisis portuguesa', El País, 18 May. Online. Available http://cultura.elpais.com/cultura/2015/05/18/actualidad/1431937062_807790.ht ml (04 March 2016). 
Bergfelder, Tim (2005), 'National, Transnational or Supranational Cinema?:

Rethinking European Film Studies', Media, Culture \& Society 27(3) pp. 31532.

Dennison, Stephanie (ed) (2013), Contemporary Hispanic Cinema: Interrogating the Transational in Spanish and Latin American Film, Woodbridge: Tamesis.

Ezra, Ezra and Terry Rowden (eds) (2006), Transnational Cinema: The Film Reader, London: Routledge.

Falicov, Tamara (2013), 'Ibero-Latin American Co-productions: Transnational Cinema, Spain's Public Relations Venture or Both,' in Stephanie Dennison (ed), Contemporary Hispanic Cinema: Interrogating the Transational in Spanish and Latin American Film, Woodbridge: Tamesis. pp, 67-88.

Faulkner, Sally (2015), 'Cinephilia and the Unrepresentable in Miguel Gomes' Tabu (2012)', Bulletin of Spanish Studies 92 (3), pp. 341-60.

Ferreira, Carolin Overhoff (2006), ‘The Limits of Luso-Brazilian Brotherhood: Fortress Europe in the Film Foreign Land', Third Text 20 (6), pp. 733-43 Ferreira, Carolin Overhoff (2012), Identity and Difference: Postcoloniality and Transnationality in Lusophone Films, Berlin: Lit Verlag.

Ferreira, Carolin Overhoff (2014), 'The End of History Through the Disclosure of Fiction: Indisciplinarity in Miguel Gomes's Tabu (2012)', Journal of Philisophy and the Moving Image v.5, pp. 18-47.

Fonseca, Rodrigo (2012), 'Mostra de cinema português começa nesta terça discutindo a crise econômica lusa' (26 June 2012). Online. Available http://oglobo.globo.com/cultura/mostra-de-cinema-portugues-comeca-nestaterca-discutindo-crise-economica-lusa-5313532 (20 November 2014). 
Galperin, Hernan (1999), 'Cultural Industries Policy in Regional Trade Agreements: the Cases of NAFTA, the European Union and MERCOSUR'. Media, Culture \& Society 21 (5), pp.627-48.

Gomes, Miguel e Luís Urbano (2013), 'Cinema português: o alarme soa', Público, 31 August. Online. Available http://publico.pt/opiniao/jornal/cinema-portugues-oalarme-soa-27028888 (20 November 2014).

Higbee, Will and Lim, Song Hwee (2010), 'Concepts of transnational cinema: towards a critical transnationalism in film studies', Transnational Cinemas 1 (1), pp. 7-21.

Higson, Andrew (1989), 'The Concept of National Cinema', Screen 30 (4), pp. 36-46.

Higson, Andrew (2006), 'The Limiting Imagination of National Cinema', in: Elizabeth Ezra and Terry Rowden (eds), Transnational Cinema: The Film Reader, London: Routledge, pp. 15-25.

ICA, 2016, ‘Apresentação’. Online. Available http://www.ica-ip.pt/pt/o-ica/quemsomos/apresentacao/ (08 March 2016).

ICA, 2015, 'Obras Nacionais Produzidas 2005-2014'. Online. Available http://www.ica-ip.pt/Admin/Files/Documents/contentdoc1881.pdf (26 May 2015).

ICA, 2014a, 'Quadro Resumo 2004-2013'. Online. Available http://www.icaip.pt/pagina.aspx?pagina $=500$ (20 November 2014).

ICA, 2014b, 'Ranking dos Filmes mais Vistos 2004-2013'. Online. Available http://www.ica-ip.pt/Admin/Files/Documents/contentdoc1958.pdf (20 November 2014).

ICA, 2014c, 'Ranking dos Filmes Nacionais mais Vistos 2004-2013'. Online. Available http://www.ica-ip.pt/Admin/Files/Documents/contentdoc1959.pdf 
(20 November 2014)

Iordanova, Dina and Cheung, Ruby (eds) (2010), Film Festival Yearbook 2: Film

Festivals and Imagined Communities, St Andrews: St Andrews Film Studies.

Kourelou, Olga, Mariana Liz, and Vidal, Belén (2014), 'Crisis and creativity: The new Cinemas of Portugal, Greece and Spain', New Cinemas 12 (1+2), pp. $133-151$

Moisés, José Alvares (2003), 'A New Policy for Brazilian Cinema', in Lúcia Nagib (ed), The New Brazilian Cinema. London: I.B. Tauris, pp. 3-21.

Nagib, Lúcia (ed) (2003), The New Brazilian Cinema, London: I.B. Tauris.

Newman, Kathleen (2010), 'Notes on Transnational Film Theory: Decentred

Subjectivity, Decentred Capitalism', in Nataša Durovicová, Kathleen E.

Newman (eds), World Cinemas, Transnational Perspectives, Abingdon, Oxon:

Routledge, pp. 3-11.

Oricchio, Luiz Zanin (2003), Cinema de novo: Um balanço crítico da retomada, São Paulo:

Estação Liberdade.

Page, Joanna (2009), Crisis and Capitalism in Contemporary Argentine Cinema,

Durham and London: Duke University Press.

Pinazza, Natália (2014), Journeys in Argentine and Brazilian Cinema, New York:

Palgrave Macmillan.

Sabine, Mark (2010), 'Putting Violence back in the Picture: Margarida Cardos's “A Costa dos Murmúrios" and Post-Colonial War Anamnesis, in Helena Golçalves da Silva and ET AL (eds), Conflict, Memory Transfers and the Reshaping of Europe, Newcastle: Cambridge Scholars' Press, pp. 291-302. 
Shaw, Deborah (2013), 'Deconstructing and Reconstruction "Transnational

Cinema"', in Stephanie Dennison (ed), Contemporary Hispanic Cinema:

Interrogating the Transational in Spanish and Latin American Film,

Woodbridge: Tamesis. pp, 47-66.

Shaw, Deborah (2003), Contemporary Cinema of Latin America: Ten Key Films, London: Continuum.

Ursini, Nathalie (2013), 'Lei de cotas nacionais na TV paga vai bem'. ANCINE. 08 August. Online. Available

http://www.ancine.gov.br/sites/default/files/clipping/2013- 08-08-

Lei\%20de\%20cotas\%20nacionais\%20na\%20TV\%20paga\%20vai\%20bem.pdf (20

November 2014).

Villarmea Álvarez, I. (2016), 'Mudar de Perspetiva: A Dimensão Transnacional do Cinema Português Contemporâneo.' Aniki : Revista Portuguesa da Imagem em Movimento, 3 (1), pp. 101-120. Available

$<$ http://aim.org.pt/ojs/index.php/revista/article/view/212 (13/04/2016).

\footnotetext{
1 The law that created IPC is available at: http://www.ica-ip.pt/pt/o-ica/quem-somos/apresentacao/ (accessed 15 May 2016)

${ }^{2}$ Online petition: http://peticaopublica.com/pview.aspx?pi=ULTIMATO (accessed 15 May 2016).
} 